ECONOMICS

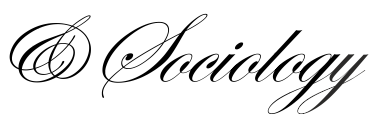

\title{
ERROR MONITORING AS AN ORGANISATIONAL INNOVATION IN PUBLIC HOSPITAL ACTIVITY
}

\author{
Agnieszka Kister, \\ Maria Curie-Sklodowska \\ University, Lublin, Poland \\ E-mail:agnieszka.kister@ \\ poczta.umcs.lublin.pl
}

Received: April, 2019

1st Revision: August, 2019

Accepted: November, 2019

DOI: $10.14254 / 2071-$

789X.2019/12-4/13
JEL Classification: B23, M12, D79
ABSTRACT. Errors in medical and administrative activities in public hospitals, along with the analysis of the sources of such errors, support the implementation of organisational innovation. The objective of this article is to compare the answers of hospital managerial staff and nursing staff with regard to identifying the reasons for the occurrence of errors as well as the improvements made in medical and non-medical activity. Empirical research seeks to provide insight on the perception of sources of errors in medical and administrative activities and the types of organisational improvements. The questionnaire was addressed to public hospital directors and nurses employed in healthcare institutions over the period of 2017-2018. It provides empirical evidence of slight differences in identification of the error sources from the hospital directors' and nurses' perspectives. The study demonstrates a connection between error occurrence and the implementation of organisational innovations and points to the factors which may facilitate the implementation process of organisational innovations. Last but not least, the findings suggest that it is essential to take into consideration the views of the staff employed by an organisation, in this case - the nurses' opinions.

Keywords: organisational innovations, healthcare, public hospital, medical errors, administrative errors

\section{Introduction}

Organisations active in the public health sector, including public hospitals, require not only constant technological but also organisational changes. The reason for this is the desire to meet the changes in the community as well as the growing demand of patients, society and the country regarding the efficient provision of high quality healthcare services and improvement of the population's overall health level. The activities of such organisations take place in an unstable and complex environment (Thakur et al., 2012), which further hinders the implementation of a given form of innovation. As research shows, implementation and diffusion of innovations in public organisations are often preconditioned by political pressure (Kimberly \& Evanisco, 1981; Schultz et al., 2012; Lindlbauer \& Schreyögg, 2014). The issue of implementing organisational innovations (OI) emerges as particularly important one due to a number of reasons. First of all, with a view to respect the European Union's health programme (European Commission, 2010), hospitals and other healthcare units must change their approach. 
The programme envisages an increase in the innovativeness, effectiveness and sustainability of healthcare systems. Secondly, changes to national legislation in Poland aimed at improving the quality of healthcare services and patient safety necessitate the introduction of organisational changes in all healthcare units. Therefore, solving the problem of monitoring quality and ensuring patient safety requires a broader view of the issue of OI (A draft Law on the Quality of Healthcare and Patient Safety). Furthermore, implementation of OI becomes an alternative to implementing changes, as diffusion of innovation does not always involve an increase in expenditures on the healthcare system. Introduction of successive reforms in the healthcare system of Poland is often justified by the statement that public hospitals are frequently underfunded. Furthermore, it seems essential to note that OI are among the solutions enhancing the operation of organisations, but only provided that the institution does not experience significant employment growth. Poland has been observing a constant decrease in the number of healthcare professionals among both physicians and nurses (System of statistics on health care). Another reason is the fact that availability of medical personnel is the factor of competitiveness in the healthcare market. What is more, the study on OI in hospitals has also been undertaken due to the fact that the researched innovation-related problem has not been fully recognised (Olsson et al., 2005; Alves et al., 2018). Finally, certain links might exist between such innovations and the occurrence of medical and administrative errors in public hospital activity, between costs (as the implemented innovations may reduce their levels), the increase in quality of the offered healthcare services or the concurrent reduction of costs and quality improvement of the performed services.

The objective of this article is to compare the answers of hospital managerial staff and nursing staff with regard to identifying the reasons for the occurrence of errors as well as the improvements made in medical and nonmedical activity.

\section{Defining organisational innovations}

The notion of innovation has been defined by numerous researchers (Damanpour, 1992; Baregheh et al., 2009; Palencia-Sánchez, Bloom et al., 2013; Sahni, 2013; Damanpour, 2014; Kapoor et al., 2014a; Kapoor et al., 2014b; García-Ubaque, 2016). Authors of the Oslo Manual highlight the significance of OI, which together with marketing and technological innovations give a much broader perspective, provide the possibility of identifying the changes which influence the effectiveness and contribute to knowledge consolidation within a given organisation (Oslo Manual, 1995; Kraśnicka, Głód, Wronka, 2014). Innovations entail the implementation of new organisational methods in work organisation and external relations, with particular reference to new organisational methods connected with, for instance, employees' work, creating procedures, or relations with the social environment (Armbruster et al., 2008). Innovations are also an essential element of managerial skills and facilitate achieving success by organisations through the efficient use of their resources (Damanpour \& Schneider, 2008; Damanpour, 2009). Research into the subject of innovations covers mainly the area of technological innovations (McDonald \& Srinivasan, 2004; Rudawska, 2011; Damanpour \& Arvind, 2012), also in the case of healthcare services and medical care (Greenhalgh et al., 2004). Studies point to issues such as the identification of these aspects of innovations which facilitate or impede the implementation of decision-making procedures within an organisation, or recognising the reasons for innovation diffusion in hospitals (Banker, Conrad \& Strauss, 1986; Gallouj, 2004; Duckers et al., 2011).

The need to innovate becomes apparent once the funding of public entities is limited. Innovations function as primary means of improving effectiveness, efficiency and quality of the provided public services (Boyne et al., 2005; Jung \& Lee, 2016). These circumstances have been further examined by Lam (2004). Such organisations are marked by professional 
bureaucracy with decentralised organisational structures. Other difficulties pertain to issues with specified quality systems or accreditation systems adopted by the organisation.

Public organisations employ new methods, concepts and management techniques to implement innovations (Birkinshaw et al., 2008; De Vries et al., 2016; Damanpour, 2014). Various types of innovations implemented by public entities include, inter alia, Balanced Scorecard, management based on the results obtained (Van Dooren \& Thijs, 2010; HijalMoghrabi, 2017) and budgeting. Such innovations do not always deliver the expected results (Damanpour \& Schneider, 2006; Bouckaert \& Halligan, 2008; Arundel et al., 2015).

Organisational innovations may be considered in three aspects. The first refers to external relations which involve crossing the borders of the public hospital, and pertaining to, i.a., the creation of hospital networks, the functioning and organisation of procurement groups, the development of coordinated healthcare, outsourcing, and cluster formation. The second aspect revolves around internal organisational activities relating to work positions, e.g. changes in employee working hours, standards systems, the quality of work and administrative services, changes in training systems, planning, motivation and staff control. The third aspect relates to a new division of responsibilities among hospital organisational units; the merging or creation of new units (e.g. wards or clinics); and the changes in information flow and executive decisionmaking. The efficient implementation of innovative solutions is recognised and rated by the reduction of error occurrence in public hospital activity. The following study will focus on the analysis of two of the aforementioned aspects, excluding the one dealing with relations between hospitals and the social environment.

\section{Errors as drivers of the implementation and diffusion of organisational innovations}

Literature review provides insight into the factors of the implementation and diffusion of OI. Errors emerge as one of the sources of these innovations, as they trigger subsequent corrective, remedial and improvement activities. As research reveals, knowledge is one of the key factors of influence, however, according to Tasselli, it does not affect the implementation of innovation in equal measure (Tasselli, 2015), mainly due to differences in professional positions between the employed. OI implementation is also affected by organisational framework, as public hospitals have a set hierarchy and division of labour. Another factor weighing in favour of the implementation of organisational innovation is the existence of a social system with a defined pattern of interpersonal relations (Pauget \&Wald 2013; Pauget $\& W a l d, 2018)$. OI are triggered by changes in the social system, but they may also be a result of the change of the system itself (Fuglsang \& Sundbo, 2005). Therefore, it may be said that knowledge, organisational structure and relations all prompt innovation. Another factor driving the implementation of OI is the mere fact that errors happen. With regard to public hospitals, they are connected with the inadequate performance of medical and nonmedical (administrative) activities (Kister, 2018). In the case of medical errors, these are the practices which fail to follow the established norms and procedures and contribute to an inadequate quality of services provided.

Medical errors do not only encompass occurrences which result from improper treatment or misdiagnosis. They may also be associated with poor work organisation, which involves, for instance, improper medication storage, incorrect labelling, medical records inconsistent with the patient's health condition, or management negligence (Lisiecka, CzyżGwiazda, Lisiecka-Biełanowicz, 2017, pp. 60-62). Administrative errors are connected with insufficient quality in administrative processes. This entails the improper performance of staff's administrative duties, errors in documentation or working time organisation, and overlapping employee responsibilities. 
What supports the consideration of error monitoring as a factor relevant to OI is the fact which arises from the draft Law on the Quality of Healthcare and Patient Safety pointing to the insufficient legislative rules pertaining to quality. Furthermore, there are frequent problems with invoking liability in the event of an inadequate quality of services. In addition, the explanatory memorandum to the draft regulation highlights the lack of sufficient knowledge about the existing levels of quality among healthcare professionals; it lacks detailed definitions of the liability for providing inadequate quality; there are also problems, inter alia, with the implementation of procedures. Hospitals have been imposed an obligation to monitor errors and to hold the ones committing them accountable.

Errors in hospital activity are revealed as a consequence of the supervision performed by control institutions created for that purpose, complaints by patients or their families or selfauditing. From the analysis of auditing activities undertaken by external entities it may be observed that among the controlled areas of hospital activity are employee documentation, public and legal settlements, medical records, health and safety at work, financial management, settling of accounts and supervision over medical services, employment and employment security, ownership and organisational transformations, infrastructure and equipment, the quality of the provided services, and patient safety. The control also covers the correctness and adequacy of procedures, the evaluation of the extent of benefits provision, establishing the causes of exceeding material and financial plans (in part or for the entire period for which agreements were concluded), verifying whether physicians provide medical services in places stipulated in the contracts and whether they use the equipment set out in those contracts, checking documentation of medical services, verification of medical staff's qualifications and verifying physicians' working time, providing medical staff with a given number of hospital beds, and the reliability of the provided services in accordance with regulatory requirements laid down by the Prime Minister (Kister, 2018).

\section{Methods and materials}

Quantitative studies were conducted over the period of 2017-2018 by a survey. The questionnaires were addressed to directors and nursing staff employed in public hospitals in Lublin region, where there are 35 such organisations. Feedback was obtained from 21 hospitals, i.e. $60 \%$. It was assumed that the results of studies in other public hospitals would be similar. Hospitals which gave consent to conducting the survey were sent questionnaires both by post and via electronic mail. The directors completed the questionnaires themselves and have designated up to six nurses from different wards. The feedback from nurses amounted to 109 replies.

The survey questionnaire concerned the sources of error occurring in two areas of hospital activity (medical and nonmedical) and questions concerning the types of improvements. The questionnaire contained closed questions, with the exception of two open-ended ones which allowed the respondent to formulate their own answers. The opinions were evaluated on the five-point Likert scale. The questionnaire also included questions concerning the name of the hospital. The remaining data, e.g. regarding respondent's sex and place of residence, were not considered relevant for the study and therefore omitted.

The data were statistically analysed using STATISTICA version 13 software. Absolute (n) and relative numbers (\%) of answers for questions as well as means (M) with standard deviations (SD) were estimated. Mann-Whitney's U test was used to compare answers for questions between directors and nurses. The value of $p<0.05$ was considered as a significant difference. 


\section{Results}

This study considered errors occurring in hospital medical and administrative activity as drivers facilitating organisational innovations. It analysed the factors with influence on the occurrence of administrative errors from the perspective of directors - people in charge of the hospital (Tab. 1) and of the nursing staff (Tab. 2). Tab. 1 contains the answers of hospital executives with reference to factors which affect the occurrence of errors in administrative activity. According to them, significant factors in this area are: a large number of legal acts, improper work organisation, lack of knowledge sharing, common errors (with average answers around 4). The answers to the same question supplied by nurses were dissimilar (Tab. 2). This group of respondents pointed to too many administrative workers, failure to follow administrative procedures, employee turnover, a large number of legal acts, staff absenteeism, and a lack of knowledge sharing. It may be concluded that nurses are not entirely convinced about the nonmedical character of the sources of errors. This table shows the significant differences between the responses of the respondents. The biggest differences concerned factors such as: common errors and too many administrative workers. Respondents pointed to the similar factors influencing administrative error occurrence such as: employee turnover, failure to follow administrative procedures and staff absenteeism.

Tab. 3 shows directors' replies concerning the types of improvements in the administrative area. The analysis of the answers shows that the indicated improvements: in the most part referred to strengthening communication between hospital employees (with a mean of 4.4), to a slightly lesser extent the introduction of increased supervision over documentation (a mean of 4.0), and to the slightest degree the replies referred to more frequent organisation of training courses, frequent analyses of employee job descriptions, and defining a new job description (with mean answers 3.8, 3.6 and 3.4 respectively). Again, the responses given by nurses differed (Tab. 4). As the most important type of improvement they indicated frequent job description analyses (a mean of 4.0). The rest of the answers had means as follows: $2.8-$ more frequent organisation of training courses, 2.7 - strengthening communication between hospital employees, 2.6 - the introduction of increased supervision over documentation, $2.3-$ defining a new job description.

Significant differences in the responses of two groups of respondents were pointed out. The most significant differences concerned the perception of two improvements: frequent analyses of the scope of employee's job description and strengthening communications between hospital employees. Respondents agreed that defining a new job description is an improvement of the administrative area.

The respondents were also asked about the factors which triggered medical errors. The replies were collated in Tab. 5 and Tab. 6. Hospital directors rated human errors as the greatest cause of inaccuracies (a mean of 4.3). The answers included failure to comply with medical procedures, improper work organisation, work overload, and shortage of medical staff. The other group - nurses - gave different replies. Staff absenteeism emerged as the most important cause (a mean of 4.0), followed by the a large number of legal acts, improper work organisation, improper interpretation of procedures and regulations, and the internal control deficiencies (a mean of 3.9). Insufficient number of training courses, common errors and too many administrative workers turned out the significant difference between the respondents' answers. The other significant differences in the replies concerned: failure to follow administrative procedures, a lack of knowledge sharing and work overload.

Next step after the identification of errors in both types of hospital activity is to implement improvements. Therefore, both groups of respondents were asked to identify such, and their answers were collated in Tab. 7 and Tab. 8. The analysis of the answers provided by hospital management demonstrated that improvements in medical activity relate mostly to: 
strengthening communication between employees and introducing increased supervision over following procedures (with respective means of 4.2 and 4.1), and also more frequent organisation of training courses (a mean of 3.8). To a lesser extent the improvements pertained to more frequent analyses of job description and defining a new job description (mean answers of 3.4 and 3.2 respectively). The responses provided by the nursing staff once again differed from the answers supplied by the managers, although, similarly to the directors, they also indicated the defining a new job description (a mean of 3.2) and the frequent analyses of the scope of employee's job description (a mean of 3.4). Significant differences in responses were received with regard to the introducing of increased supervision over following procedures and the strengthening communication between health professionals.

It ought to be emphasized that in comparison with doctors' responses, the factors pointed out by nurses bore less influence on the occurrence of administrative and medical errors.

\section{Discussion of the findings}

The research findings show that there is a link between the identification of errors occurring in hospital medical and non-medical activity, and OI. The identification and analysis of errors as facilitators of innovation is a relatively low-cost method which does not lead to an increase in costs. According to Tornatzky \& Klein (1982), inexpensive innovations will have a greater chance of being immediately adopted and implemented, in comparison with more expensive ones. Data on errors are connected with the process of communicating innovation, or the diffusion of innovation among members of the social system (Rogers, 1983; Feeny \& Rogers, 2003; Tawfik et. al., 2018). Monitoring errors is an efficient method of implementing improvements in organisations, as it exposes the inefficient areas (Savall, 2010; Anderson, et al., 2013), triggers the undertaking of corrective and remedial activities, and leads to organisational improvements in the form of a change in the approach regarding management of the organisation (Canadian Institute for Health Information, 2016; Kister, 2018).

The conclusions drawn in this article are founded on the results of a questionnaire. This form of data collection is becoming increasingly popular. However, as Häggman (2009) claims, in order to study the perception of innovation by different actors, one should rather employ the methodology of a case study.

The implementation of OI identified in this article, as the monitoring of errors in both areas of hospital activity, ought to entail the implementation of further innovations, as proven by Favoreu, Maurel, Carassus et al. (2018). Furthermore, as other researchers also claim, various forms of innovations are interdependent, thus it is necessary to adopt a comprehensive and integrated approach towards this issue (Damanpour, 2014; Bocquet \& Dubouloz, 2015). On a global scale, one may also notice a growing interest among public organisations, including health care facilities, in programmes targeted at the support and diffusion of organisational innovations (Walker \& Boyne, 2006; Arundel et al., 2005). Among the types of innovations applied by public hospitals, one can enumerate activities such as the implementation of the Balanced Scorecard, management based on results (Van Dooren \& Thijs, 2010; HijalMoghrabi, 2017), or activity-based budgeting. However, the implementation of innovations in the public sector does not always yield the expected results. There are also several noticeable differences in the pace, rate of adoption and diffusion of innovations (Bouckaert \& Halligan, 2008).

Literature has been used to identify strategies for an effective safety culture and prevention of errors in the case of health professionals. The authors analysed the results of 12 articles. Teamwork and communication were found to be cited as key measures in $75 \%$ of the studies; $66.7 \%$ reinforces the importance of error reporting; $58.3 \%$ says training/permanent 
improvement is necessary; $33.3 \%$ takes into account global perceptions of safety and the importance of trust in leaders as an effective method; $25 \%$ points to the importance of error feedback for health professionals (Vinagre \& Marques, 2018). These are similar research results, although they concern only one professional group - nurses. They indicate, among others, that feedback about errors is important. Therefore, it can be concluded that reports of mistakes are a source of innovative solutions.

\section{Conclusion}

The introduction and diffusion of organisational innovations is driven by many factors, which have been widely reviewed in literature concerning innovation. It appears that among such factors one may consider the fact that hospitals operate within specific legal, political, social and economic environments. Innovations might be triggered by the growing expectations of hospital stakeholders, but also by certain managerial decisions. Another factor which facilitates innovative activities is error occurrence in both types of hospital activity: medical and administrative. In order to identify errors, it is advantageous to make use of control reports provided by auditing bodies which inspect a wide spectrum of public hospital activities discussed in the article. In the case of medical errors, the managerial staff usually learns about these from patients. Self-auditing also proves useful in the identification of errors.

All kinds of errors should be subjected to thorough analyses, among others with regard to identifying their causes and the subsequent implementation of corrective and remedial measures. The conducted research proves that, from the perspectives of two groups of hospital employees - physicians and nurses, there are different factors which influence the occurrence of medical and administrative errors. Therefore, hospital executives ought to examine the entire range of errors and implement improvements. The results of this study may prove practical and useful in this respect, as it delivers answers identified by the respondents, pertaining not only to the causes of error occurrence, but also to the types of improvements they deem relevant to be implemented. One of the crucial improvements recognised by both groups of respondents is the need to strengthen communication between hospital employees. It is considered the key activity in the case of both medical and administrative areas.

The results of the questionnaire will also help raise the awareness of health professionals that there are problems with error occurrence with regard to hospital's medical and administrative activity. Answers provided by the nursing staff should be thoroughly analysed and collated with their proposals of improvements. Decisions pertaining to the implementation of OI ought to be made jointly by the executives and other employees. The changing of inefficient work organisation, the introduction of increased supervision over following medical procedures, the more frequent conduction of on-the-job training and the implementation of selected efficiency incentives are among the solutions which do not require increased financial resources. The identified proposals of changes may have a positive impact on the work environment and work results. The obtained results of this study identify the ways in which the managerial staff can manage the innovation process. The author proves the existence of a connection between error occurrence and the implementation of OI. The research also defines the factors which may trigger and facilitate the process of OI adoption. Finally, the article gives evidence that organisational innovations ought to be implemented not only by managers, but also consulted with other employees of public hospitals. The manner of dealing with errors ought to be consolidated and made known to all employed persons, especially in the case of medical errors, as their consequences might result in patient loss of health or life. On the one hand, such occurrences may negatively influence and impede OI but, on the other hand, they frequently occasion OI. Furthermore, administrative errors may also constitute a serious problem hindering OI implementation. The lack of awareness concerning the impact of such 
errors may have subsequent negative consequences, such as developing bad habits which, in turn, may lead to poorer work performance and hinder OI diffusion and implementation.

The research shows that there are significant differences in the perception of factors by directors and nurses influencing the occurrence of errors in the medical and non-medical areas. Further research should be devoted to analysing the causes of this phenomenon.

\section{Acknowledgement}

The publication of this work was co-financed from the funds of the Minister of Science and Higher Education in Poland, designated to research propagating activities (No. 776/PDUN/2018).

\section{References}

Anderson, J. E., Kodate, N., Walters, R. et al. (2013). Can incident reporting improve safety? Healthcare practitioners' views of the effectiveness of incident reporting. Int J Qual Health Care, 25, 141-50.

Alves, M. F. R., Galina, S. V. R., Dobelin, S. (2018). Literature on organizational innovation: past and future. Innovation \& Management Review, 15(1), 2-19.

Arundel, A., Casali, L. \& Hollanders, H. (2015). How European public sector agencies innovate: The use of bottom-up, policy-dependent and knowledge-scanning innovation methods. Research Policy, 44(7), 1271-1282.

Banker, R. D., Conrad, R. F., \& Strauss, R. P. (1986). A comparative application of data envelopment analysis and translog methods: an illustrative study of hospital production. Management Science, 32(1), 30-44.

Baregheh, A., Rowley, J. \& Sambrook, S. (2009). Towards a multidisciplinary definition of innovation. Management Decision, 47(8), 1323-1339.

Birkinshaw, J., Hamel, G. \& Mol, M. J. (2008). Management innovation. Academy of Management Review, 33(4), 825-45.

Bloom, N., Romer, P. M., Terry, S. J. \& Van Reenen, J. (2013). A trapped-factors model of innovation. American Economic Review, 103(3), 208-213.

Bouckaert, G. \& Halligan, J. (2008). Managing performance: International comparisons; New York: Routledge.

Boyne, G. A., Law, J. S. \& Walker, R. M. (2005). Explaining the adoption of innovation: An Empirical Analysis of Public Management Reform. Environment and Planning: Government and Policy, 23(3), 419-435.

Camisón, C. \& Villar-López, A. (2014). Organizational Innovation as an Enabler of Technological Innovation Capabilities and Firm Performance. Journal of Business Research, 67, 2891-2902.

Canadian Institute for Health Information, Canadian Patient Safety Institute. (2016). Measuring Patient Harm in Canadian Hospitals. With What can be done to improve patient safety? authored by Chan, B., Cochrane, D., Ottawa, ON: CIHI.

Damanpour, F. (1992). Organizational Size and Innovation. Organization Studies, 13(3), 375402.

Damanpour, F. \& Schneider, M. (2006). Phases of the adoption of innovation in organizations: Effects of environment, organization and top managers. British Journal of Management, 17(3), 215-236.

Damanpour, F. \& Schneider, M. (2008). Characteristics of innovation and innovation adoption in public organizations: Assessing the role of managers. Journal of Public Administration 
Research and Theory, 19(3), 495-522.

Damanpour, F., Arvind, D. (2012). Managerial Innovation: Conceptions, processes, and antecedents. Management and Organization Review, No. 8, 423-454.

Damanpour, F., Walker, R. M. \& Avellaneda, C. N. (2009). Combinative effects of innovation types and organizational performance: a longitudinal study of service organizations. Journal of Management Studies, Vol. 46, No. 4, 650-675.

Damanpour, F. (2014). Footnotes to research on management innovation. Organization Studies, Vol. 35, No. 9, 1265-1285.

De Vries, H., Bekkers, V., \& Tummers, L. (2016). Innovation in the Public Sector: a Systematic review and Future Research Agenda. Public Administration, 94(1), 146-166.

Djellal, F., Gallouj, C., \& Gallouj, F. (2004). De l'hôpital-fonction de production à l'hôpital service complexe et nœud de réseaux, Les différentes facettes de l'innovation hospitalière. Dans Revue française des affaires sociales, 1, http://www.cairn.info/revue-francaise-desaffaires-sociales-2004-1-page-223.htm.

Duckers, M. L. A., Wagner, C., Vos, L., \& Groenewegen, P. P. (2011). Understanding organisational development, sustainability, and diffusion of innovations within hospitals participating in a multilevel quality collaborative. Implementation Science, 6:18.

Draft law on the Quality of Health Care and Patient Safety.

European Commission. (2010). Comunication from the Commission Europe 2020: a strategy for smart, sustainable and inclusive growth. Brussels: European Commission.

Favoreu, C., Maurel, C., Carassus, D. et al. (2018). Influence and Complementarity of Followon Managerial Innovations within a Public Organization. Public Organization Review, $1-21$.

Feeny, S. \& Rogers, M. (2003). Innovation and performance: Benchmarking Australian firms. Australian Economic Review, 36(3), 253-264.

Fuglsang, L. \& Sundbo, J. (2005). The organizational innovation system: three modes. Journal of Change Management, 5(3), 329-344.

González-Blanco, J., Coca-Pérez, J. L. \& Guisado-González, M. (2018). Relations between technological and non-technological innovations in the service sector. The Service Industries Journal, 39(2), 134-153.

Greenhalgh, T., Robert, G., Macfarlane, F., Bate, P., Kyriakidou, O. (2004). Diffusion of innovations in service organizations: systematic review and recommendations. The Milbank Quarterly, 82(4), 581-629.

Häggman, S. K. (2009). Functional actors and perceptions of innovation attributes: influence on innovation adoption. European Journal of Innovation Management, 12(3), 386-407.

Hijal-Moghrabi, I. (2017). The current practice of performance-based budgeting in the largest U.S. cities: An innovation theory perspective. Public Performance \& Management Review, 40(4), 652-675.

Jung, C. H. \& Lee, G. (2016). Organizational climate leadership, organizational size and aspiration for innovation in government agencies. Public Performance \& Management Review, 39(4), 757-782.

Kapoor, K. K., Dwivedi, Y. K., \& Wiliams, M. D. (2014a). Innovation adoption attributes: a review and synthesis of research findings. European Journal of Innovation Management, 17(3), 327-348.

Kapoor, K. K., Dwivedi, Y. K., \& Williams, M. D. (2014b). Rogers' Innovation Adoption Attributes: A Systematic Review and Synthesis of Existing Research. Information Systems Management, 31(1), 74-91.

Kimberly, J. R. \& Evanisco, M. (1981). Organizational innovation: The influence of individual, organizational, and contextual factors on hospital adoption of technological and administrative innovations. Academy of Management Journal, 24, 689-713. 
Kister, A. (2018). Koszty niezgodności $w$ doskonaleniu jakości zarzadzania szpitalem publicznym [Costs of non-compliance in improving the quality of public hospital management]. Wydawnictwo UMCS. Lublin.

Kraśnicka, T., Głód, W., \& Wronka-Pośpiech, M. (2018). Management innovation, proinnovation organisational culture and enterprise performance: testing the mediation effect. Review of Managerial Science, 12(3), 737-769.

Lam, A. (2004). Organizational innovation. Royal Holloway College. University of London.

Lindlbauer, I., \& Schreyögg, J. (2014). The relationship between hospital specialization and hospital efficiency: do different measures of specialization lead to different results? Health care management science, 17(4), 365-378.

Lisiecka, K., Czyż-Gwiazda, E., \& Lisiecka-Biełanowicz, M. (2017). Projakościowe zarzadzanie $w$ organizacjach ochrony zdrowia [Quality management in health care organizations]. Wydawnictwo Uniwersytetu Ekonomicznego w Katowicach, Katowice.

Lux, G., \& Petit, N. (2016). Coalitions of Actors and Managerial Innovations in the Healthcare and Social Healthcare Sector. Public Organization Review, 16(2), 251-268.

McDonald, R. E., \& Srinivasan, N. (2004). Technological innovations in hospitals: what kind of competitive adventage does adoption lead to?. International Journal of Technology Management, 28(1).

Meroño-Cerdán, Á. L., \& López-Nicolás, C. (2017). Innovation objectives as determinants of organizational innovations. Innovation Organization \& Management, 19(2), 208-226.

Olsson, J., Kammerlind P., Thor, J., Elgh, M. (2005). Surveying Improvement Activities in Health Care on a National Level - The Swedish Internal Collaborative Strategy and its Challenges. Quality Management in Healthcare, 12(4), 202-216.

Oslo Manual. Guidelines for collecting and interpreting innovation data. (2005). III edn. OECD Publishing.

Pauget, B., \& Wald, A. (2013). Relational competence in complex temporary organizations: The case of a French hospital construction project network. International Journal of Project Management, 31(2), 200-2011.

Pauget, B. \& Wald, A. (2018). Creating and implementing organizational innovation: The role of professional identity and network embeddedness in healthcare organizations. European Journal of Innovation Management, 21(3), 384-401.

Palencia-Sánchez, F. \& García-Ubaque, J. C. (2016). Innovation and research in university hospitals. Revista de la Facultad de Medicina, 64(4), 741-747.

Rogers, E. M. (1983). Diffusion of innovations. New York: Free Press.

Rudawska, I. (2011). Zintegrowana opieka zdrowotna: w poszukiwaniu poprawy efektywności [Integrated Healthcare: in search of improved effectiveness]. Problemy Zarzadzania, $9(3), 140-152$.

Sahni, N. R., Wessel M., \& Christensen C. (2013). Unleashing breakthrough innovation in government. Stanford Social Innovation Review, 11, 27-31.

Schultz, J. \& Urban, J. M. (2012). Protecting open innovation: The defensive patent license as a new approach to patent threats, transaction costs, and tactical disarmament. Harv. JL \& Tech., 26, 1.

Thakur, R., Hsu, S. H., \& Fontenot, G. (2012). Innovation in healthcare: Issues and future trends. Journal of Business Research, 65(4), 562-569.

Tasselli, S. (2015). Social networks and inter-professional knowledge transfer: the case of healthcare professionals. Organization Studies, 36(7), 841-872.

Tornatzky, L. G., \& Klein, K. (1982). Innovation characteristics and innovation adoptionimplementation: a meta-analysis of findings. IEEE Transactions on Engineering Management, 29(1).

Tawfik, D. S., Profit, J., Morgenthaler, T. I., Satele, D. V., Sinsky, C. A., Dyrbye, L. N., Tutly, 
M. A., West, C. P. \& Shanefelt, T. D. (2018). Physician burnout, well-being, and work unit safety grades in relationship to reported medical errors. Mayo Clinic Proceedings, 93(11), 1571-1580.

Van Dooren, W. \& Thijs, N. (2010). Paradoxes of improving performance management (systems) in public administration, EIPASCOPE, 15-19.

Walker, R. M. \& Boyne, J. A. (2006). Public management reform and organizational performance: An empirical assessment of the U.K. labour government's public service improvement strategy. Journal of Policy Analysis and Management, 25(2), 371-393.

Vinagre, T. \& Marques, R. (2018). Strategies for an effective safety culture and prevent errors in nursing: literature review. International Journal of Nursing (New York, NY), 5, 25-32. 


\section{Appendix}

Table 1. Factors influencing administrative error occurrence according to hospital directors

\begin{tabular}{|c|c|c|c|c|c|c|c|c|c|c|c|c|}
\hline \multirow[t]{2}{*}{ Causes of administrative errors } & \multicolumn{2}{|c|}{$\begin{array}{c}\text { strongly } \\
\text { disagree (1) }\end{array}$} & \multicolumn{2}{|c|}{$\begin{array}{c}\text { disagree } \\
(2)\end{array}$} & \multicolumn{2}{|c|}{$\begin{array}{c}\text { undecided } \\
\text { (3) }\end{array}$} & \multicolumn{2}{|c|}{ agree (4) } & \multicolumn{2}{|c|}{$\begin{array}{l}\text { strongly } \\
\text { agree (5) }\end{array}$} & \multicolumn{2}{|c|}{ total } \\
\hline & $\mathrm{n}$ & $\%$ & $\mathrm{n}$ & $\%$ & $\mathrm{n}$ & $\%$ & $\mathrm{n}$ & $\%$ & $\mathrm{n}$ & $\%$ & $\mathrm{M}$ & $\mathrm{SD}$ \\
\hline employee turnover & 1 & 4.76 & 4 & 19.05 & 4 & 19.05 & 6 & 28.57 & 6 & 28.57 & 3.6 & 1.2 \\
\hline large number of legal acts & 1 & 4.76 & 2 & 9.52 & 1 & 4.76 & 6 & 28.57 & 11 & 52.38 & 4.1 & 1.2 \\
\hline insufficient amount of training & 0 & 0.00 & 2 & 9.52 & 2 & 9.52 & 15 & 71.43 & 2 & 9.52 & 3.8 & 0.7 \\
\hline $\begin{array}{l}\text { failure to follow administrative } \\
\text { procedures }\end{array}$ & 0 & 0.00 & 2 & 9.52 & 7 & 33.33 & 7 & 33.33 & 5 & 23.81 & 3.7 & 1.0 \\
\hline failure to perform duties & 0 & 0.00 & 2 & 9.52 & 3 & 14.29 & 14 & 66.67 & 2 & 9.52 & 3.8 & 0.8 \\
\hline improper work organisation & 0 & 0.00 & 2 & 9.52 & 2 & 9.52 & 11 & 52.38 & 6 & 28.57 & 4.0 & 0.9 \\
\hline negative work environment & 0 & 0.00 & 3 & 14.29 & 7 & 33.33 & 7 & 33.33 & 4 & 19.05 & 3.6 & 1.0 \\
\hline staff absenteeism & 0 & 0.00 & 3 & 14.29 & 6 & 28.57 & 8 & 38.10 & 4 & 19.05 & 3.6 & 1.0 \\
\hline work overload & 0 & 0.00 & 3 & 14.29 & 7 & 33.33 & 10 & 47.62 & 1 & 4.76 & 3.4 & 0.8 \\
\hline common errors & 0 & 0.00 & 1 & 4.76 & 3 & 14.29 & 15 & 71.43 & 2 & 9.52 & 3.9 & 0.7 \\
\hline $\begin{array}{l}\text { bad interpretation of procedures } \\
\text { and regulations }\end{array}$ & 1 & 4.76 & 1 & 4.76 & 3 & 14.29 & 15 & 71.43 & 1 & 4.76 & 3.7 & 0.9 \\
\hline internal control deficiencies & 1 & 4.76 & 2 & 9.52 & 5 & 23.81 & 10 & 47.62 & 3 & 14.29 & 3.6 & 1.0 \\
\hline too many administrative workers & 0 & 0.00 & 12 & 57.14 & 5 & 23.81 & 4 & 19.05 & 0 & 0.00 & 2.6 & 0.8 \\
\hline lack of knowledge sharing & 0 & 0.00 & 1 & 4.76 & 2 & 9.52 & 15 & 71.43 & 3 & 14.29 & 4.0 & 0.7 \\
\hline employee laziness & 0 & 0.00 & 2 & 9.52 & 5 & 23.81 & 9 & 42.86 & 5 & 23.81 & 3.8 & 0.9 \\
\hline
\end{tabular}

Table 2. Factors influencing administrative error occurrence according to the nursing staff

\begin{tabular}{|c|c|c|c|c|c|c|c|c|c|c|c|c|c|}
\hline \multirow[t]{2}{*}{ Causes of administrative errors } & \multicolumn{2}{|c|}{$\begin{array}{c}\text { strongly } \\
\text { disagree } \\
(1)\end{array}$} & \multicolumn{2}{|c|}{$\begin{array}{c}\text { disagree } \\
\text { (2) }\end{array}$} & \multicolumn{2}{|c|}{$\begin{array}{c}\text { undecided } \\
\text { (3) }\end{array}$} & \multicolumn{2}{|c|}{ agree (4) } & \multicolumn{2}{|c|}{$\begin{array}{l}\text { strongly } \\
\text { agree (5) }\end{array}$} & \multicolumn{2}{|c|}{ total } & \multirow[t]{2}{*}{$\mathrm{p}$} \\
\hline & $\mathrm{n}$ & $\%$ & $\mathrm{n}$ & $\%$ & $\mathrm{n}$ & $\%$ & $\mathrm{n}$ & $\%$ & $\mathrm{n}$ & $\%$ & $\mathrm{M}$ & SD & \\
\hline employee turnover & 1 & 0.92 & 21 & 19.27 & 20 & 18.35 & 42 & 38.53 & 25 & 22.94 & 3.6 & 1.1 & 0.934 \\
\hline large number of legal acts & 7 & 6.42 & 16 & 14.68 & 16 & 14.68 & 53 & 48.62 & 17 & 15.60 & 3.5 & 1.1 & 0.005 \\
\hline insufficient amount of training & 14 & 12.84 & 36 & 33.03 & 15 & 13.76 & 34 & 31.19 & 10 & 9.17 & 2.9 & 1.2 & 0.002 \\
\hline $\begin{array}{l}\text { failure to follow administrative } \\
\text { procedures }\end{array}$ & 1 & 0.92 & 10 & 9.17 & 28 & 25.69 & 49 & 44.95 & 21 & 19.27 & 3.7 & 0.9 & 0.893 \\
\hline failure to perform duties & 14 & 12.84 & 26 & 23.85 & 16 & 14.68 & 44 & 40.37 & 9 & 8.26 & 3.1 & 1.2 & 0.018 \\
\hline improper work organisation & 13 & 11.93 & 27 & 24.77 & 14 & 12.84 & 41 & 37.61 & 14 & 12.84 & 3.1 & 1.3 & 0.004 \\
\hline negative work environment & 3 & 2.75 & 35 & 32.11 & 38 & 34.86 & 25 & 22.94 & 8 & 7.34 & 3.0 & 1.0 & 0.019 \\
\hline staff absenteeism & 4 & 3.67 & 24 & 22.02 & 21 & 19.27 & 42 & 38.53 & 18 & 16.51 & 3.4 & 1.1 & 0.535 \\
\hline work overload & 8 & 7.34 & 46 & 42.20 & 30 & 27.52 & 22 & 20.18 & 3 & 2.75 & 2.7 & 1.0 & 0.001 \\
\hline common errors & 9 & 8.26 & 40 & 36.70 & 26 & 23.85 & 21 & 19.27 & 13 & 11.93 & 2.9 & 1.2 & $<0.001$ \\
\hline $\begin{array}{l}\text { bad interpretation of procedures } \\
\text { and regulations }\end{array}$ & 4 & 3.67 & 30 & 27.52 & 28 & 25.69 & 42 & 38.53 & 5 & 4.59 & 3.1 & 1.0 & 0.013 \\
\hline internal control deficiencies & 10 & 9.17 & 41 & 37.61 & 23 & 21.10 & 23 & 21.10 & 12 & 11.01 & 2.9 & 1.2 & 0.009 \\
\hline $\begin{array}{l}\text { too many administrative } \\
\text { workers }\end{array}$ & 0 & 0.00 & 11 & 10.09 & 18 & 16.51 & 50 & 45.87 & 30 & 27.52 & 3.9 & 0.9 & $<0.001$ \\
\hline lack of knowledge sharing & 6 & 5.50 & 28 & 25.69 & 12 & 11.01 & 45 & 41.28 & 18 & 16.51 & 3.4 & 1.2 & 0.050 \\
\hline employee laziness & 6 & 5.50 & 40 & 36.70 & 20 & 18.35 & 35 & 32.11 & 8 & 7.34 & 3.0 & 1.1 & 0.002 \\
\hline
\end{tabular}


Table 3. Types of administrative improvements according to hospital directors

\begin{tabular}{|c|c|c|c|c|c|c|c|c|c|c|c|c|}
\hline \multirow[t]{2}{*}{ Types of improvement } & \multicolumn{2}{|c|}{$\begin{array}{c}\text { strongly } \\
\text { disagree (1) }\end{array}$} & \multicolumn{2}{|c|}{$\begin{array}{l}\text { disagree } \\
\text { (2) }\end{array}$} & \multicolumn{2}{|c|}{$\begin{array}{c}\text { undecided } \\
\text { (3) }\end{array}$} & \multicolumn{2}{|c|}{ agree (4) } & \multicolumn{2}{|c|}{$\begin{array}{l}\text { strongly } \\
\text { agree (5) }\end{array}$} & \multicolumn{2}{|c|}{ total } \\
\hline & $\mathrm{n}$ & $\%$ & $\mathrm{n}$ & $\%$ & $\mathrm{n}$ & $\%$ & $\mathrm{n}$ & $\%$ & $\mathrm{n}$ & $\%$ & $\mathrm{M}$ & SD \\
\hline $\begin{array}{l}\text { frequent analyses of the scope of } \\
\text { employee's job description }\end{array}$ & 0 & 0.00 & 1 & 4.76 & 11 & 52.38 & 7 & 33.33 & 2 & 9.52 & 3.6 & 1.0 \\
\hline defining a new job description & 0 & 0.00 & 1 & 4.76 & 10 & 47.62 & 10 & 47.62 & 0 & 0.00 & 3.4 & 0.6 \\
\hline $\begin{array}{l}\text { introducing increased supervision over } \\
\text { documentation }\end{array}$ & 0 & 0.00 & 1 & 4.76 & 1 & 4.76 & 17 & 80.95 & 2 & 9.52 & 4.0 & 0.6 \\
\hline $\begin{array}{l}\text { more frequent organisation of training } \\
\text { courses }\end{array}$ & 0 & 0.00 & 2 & 9.52 & 2 & 9.52 & 16 & 76.19 & 1 & 4.76 & 3.8 & 0.7 \\
\hline $\begin{array}{l}\text { strengthening communication between } \\
\text { hospital employees }\end{array}$ & 0 & 0.00 & 1 & 4.76 & 0 & 0.00 & 10 & 47.62 & 10 & 47.62 & 4.4 & 0.7 \\
\hline
\end{tabular}

Table 4. Types of administrative improvements according to the nursing staff

\begin{tabular}{|c|c|c|c|c|c|c|c|c|c|c|c|c|c|}
\hline \multirow[t]{2}{*}{ Types of improvement } & \multicolumn{2}{|c|}{$\begin{array}{l}\text { strongly } \\
\text { disagree } \\
(1) \\
\end{array}$} & \multicolumn{2}{|c|}{$\begin{array}{c}\text { disagree } \\
\text { (2) }\end{array}$} & \multicolumn{2}{|c|}{$\begin{array}{l}\text { undecided } \\
\text { (3) }\end{array}$} & \multicolumn{2}{|c|}{ agree (4) } & \multicolumn{2}{|c|}{$\begin{array}{l}\text { strongly } \\
\text { agree (5) }\end{array}$} & \multicolumn{2}{|c|}{ total } & \multirow[t]{2}{*}{$\mathrm{p}$} \\
\hline & $\mathrm{n}$ & $\%$ & $\mathrm{n}$ & $\%$ & $\mathrm{n}$ & $\%$ & $\mathrm{n}$ & $\%$ & $\mathrm{n}$ & $\%$ & $\mathrm{M}$ & $\mathrm{SD}$ & \\
\hline $\begin{array}{l}\text { frequent analyses of the scope } \\
\text { of employee's job description }\end{array}$ & 27 & 24.77 & 55 & 50.46 & 22 & 20.18 & 5 & 4.59 & 0 & 0.00 & 2.0 & 0.8 & $<0.001$ \\
\hline defining a new job description & 0 & 0.00 & 12 & 11.01 & 25 & 22.94 & 53 & 48.62 & 19 & 17.43 & 3.7 & 0.9 & 0.079 \\
\hline $\begin{array}{l}\text { introducing increased } \\
\text { supervision over } \\
\text { documentation }\end{array}$ & 10 & 9.17 & 22 & 20.18 & 15 & 13.76 & 43 & 39.45 & 19 & 17.43 & 3.4 & 1.2 & 0.050 \\
\hline $\begin{array}{l}\text { more frequent organisation of } \\
\text { training courses }\end{array}$ & 10 & 9.17 & 21 & 19.27 & 21 & 19.27 & 46 & 42.20 & 11 & 10.09 & 3.2 & 1.2 & 0.050 \\
\hline $\begin{array}{l}\text { strengthening communication } \\
\text { between hospital employees }\end{array}$ & 5 & 4.59 & 30 & 27.52 & 17 & 15.60 & 38 & 34.86 & 19 & 17.43 & 3.3 & 1.2 & $<0.001$ \\
\hline
\end{tabular}


Table 5. Factors influencing medical error occurrence according to hospital directors

\begin{tabular}{|c|c|c|c|c|c|c|c|c|c|c|c|c|}
\hline \multirow[t]{2}{*}{ Causes of medical errors } & \multicolumn{2}{|c|}{$\begin{array}{c}\text { strongly } \\
\text { disagree (1) }\end{array}$} & \multicolumn{2}{|c|}{$\begin{array}{l}\text { disagree } \\
(2)\end{array}$} & \multicolumn{2}{|c|}{$\begin{array}{c}\text { undecided } \\
\text { (3) }\end{array}$} & \multicolumn{2}{|c|}{ agree (4) } & \multicolumn{2}{|c|}{$\begin{array}{l}\text { strongly } \\
\text { agree (5) }\end{array}$} & \multicolumn{2}{|c|}{ total } \\
\hline & $\mathrm{n}$ & $\%$ & $\mathrm{n}$ & $\%$ & $\mathrm{n}$ & $\%$ & $\mathrm{n}$ & $\%$ & $\mathrm{n}$ & $\%$ & $\mathrm{M}$ & SD \\
\hline employee turnover & 1 & 4.76 & 3 & 14.29 & 7 & 33.33 & 7 & 33.33 & 3 & 14.29 & 3.4 & 1.1 \\
\hline large number of legal acts & 1 & 4.76 & 0 & 0.00 & 4 & 19.05 & 13 & 61.90 & 3 & 14.29 & 3.8 & 0.9 \\
\hline insufficient amount of training & 0 & 0.00 & 1 & 4.76 & 3 & 14.29 & 17 & 80.95 & 0 & 0.00 & 3.8 & 0.5 \\
\hline $\begin{array}{l}\text { failure to follow administrative } \\
\text { procedures }\end{array}$ & 1 & 4.76 & 0 & 0.00 & 2 & 9.52 & 11 & 52.38 & 7 & 33.33 & 4.1 & 0.9 \\
\hline failure to perform duties & 0 & 0.00 & 0 & 0.00 & 4 & 19.05 & 17 & 80.95 & 0 & 0.00 & 3.8 & 0.4 \\
\hline improper work organisation & 0 & 0.00 & 1 & 4.76 & 0 & 0.00 & 16 & 76.19 & 4 & 19.05 & 4.1 & 0.6 \\
\hline negative work el & 0 & 0.00 & 1 & 4.76 & 6 & 28.57 & 10 & 47.62 & 4 & 19.05 & 3.8 & 0.8 \\
\hline staff absenteeism & 0 & 0.00 & 2 & 9.52 & 6 & 28.57 & 9 & 42.86 & 4 & 19.05 & 3.7 & 0.9 \\
\hline work overload & 0 & 0.00 & 1 & 4.76 & 2 & 9.52 & 14 & 66.67 & 4 & 19.05 & 4.0 & 0.7 \\
\hline common errors & 0 & 0.00 & 1 & 4.76 & 0 & 0.00 & 12 & 57.14 & 8 & 38.10 & 4.3 & 0.7 \\
\hline $\begin{array}{l}\text { bad interpretation of procedures and } \\
\text { regulations }\end{array}$ & 0 & 0.00 & 1 & 4.76 & 2 & 9.52 & 17 & 80.95 & 1 & 4.76 & 3.9 & 0.6 \\
\hline internal control deficiencies & 0 & 0.00 & 2 & 9.52 & 1 & 4.76 & 18 & 85.71 & 0 & 0.00 & 3.8 & 0. \\
\hline too many administra & 0 & 0.00 & 0 & 0.00 & 5 & 23.81 & 10 & 47.62 & 6 & 28.57 & 4.0 & 0.7 \\
\hline lack of knowledge sharing & 0 & 0.00 & 2 & 9.52 & 3 & 14.29 & 13 & 61.90 & 3 & 14.29 & 3.8 & 0.8 \\
\hline employee laziness & 0 & 0.00 & 3 & 14.29 & 2 & 9.52 & 10 & 47.62 & 6 & 28.57 & 3.9 & 1.0 \\
\hline
\end{tabular}

$\mathrm{n}$ - number of respondents, $\%$ - share of respondents $(\mathrm{N}=21) . \mathrm{M}-$ mean, $\mathrm{SD}$ - standard deviation

Source: Author.

Table 6. Factors influencing medical error occurrence according to the nursing staff

\begin{tabular}{|c|c|c|c|c|c|c|c|c|c|c|c|c|c|}
\hline \multirow[t]{2}{*}{ Causes of medical errors } & \multicolumn{2}{|c|}{$\begin{array}{c}\text { strongly } \\
\text { disagree } \\
(1)\end{array}$} & \multicolumn{2}{|c|}{$\begin{array}{c}\text { disagree } \\
\text { (2) }\end{array}$} & \multicolumn{2}{|c|}{$\begin{array}{c}\text { undecided } \\
\text { (3) }\end{array}$} & \multicolumn{2}{|c|}{ agree (4) } & \multicolumn{2}{|c|}{$\begin{array}{l}\text { strongly } \\
\text { agree (5) }\end{array}$} & \multicolumn{2}{|c|}{ total } & \multirow[t]{2}{*}{$\mathrm{p}$} \\
\hline & $\mathrm{n}$ & $\%$ & $\mathrm{n}$ & $\%$ & $\mathrm{n}$ & $\%$ & $\mathrm{n}$ & $\%$ & $\mathrm{n}$ & $\%$ & M & $\mathrm{SD}$ & \\
\hline employee turnover & 2 & 1.83 & 27 & 24.77 & 26 & 23.85 & 43 & 39.45 & 11 & 10.09 & 3.3 & 1.0 & 0.778 \\
\hline large number of legal acts & 1 & 0.92 & 6 & 5.50 & 19 & 17.43 & 60 & 55.05 & 23 & 21.10 & 3.9 & 0.8 & 0.689 \\
\hline insufficient amount of training & 8 & 7.34 & 52 & 47.71 & 24 & 22.02 & 23 & 21.10 & 2 & 1.83 & 2.6 & 1.0 & $<0.001$ \\
\hline $\begin{array}{l}\text { failure to follow administrative } \\
\text { procedures }\end{array}$ & 5 & 4.59 & 32 & 29.36 & 19 & 17.43 & 37 & 33.94 & 16 & 14.68 & 3.2 & 1.2 & 0.002 \\
\hline failure to perform duties & 1 & 0.92 & 10 & 9.17 & 20 & 18.35 & 60 & 55.05 & 18 & 16.51 & 3.8 & 0.9 & 0.869 \\
\hline improper work organisation & 0 & 0.00 & 4 & 3.67 & 20 & 18.35 & 69 & 63.30 & 16 & 14.68 & 3.9 & 0.7 & 0.140 \\
\hline negative work environment & 0 & 0.00 & 14 & 12.84 & 16 & 14.68 & 61 & 55.96 & 18 & 16.51 & 3.8 & 0.9 & 1.000 \\
\hline staff absenteeism & 00 & 0.00 & 6 & 5.50 & 19 & 17.43 & 57 & 52.29 & 27 & 24.77 & 4.0 & 0.8 & 0.213 \\
\hline work overload & 8 & 7.34 & 29 & 26.61 & 12 & 11.01 & 45 & 41.28 & 15 & 13.76 & 3.3 & 1.2 & 0.013 \\
\hline common errors & 4 & 3.67 & 36 & 33.03 & 21 & 19.27 & 22 & 30.28 & 15 & 13.76 & 3.2 & 1.1 & $<0.001$ \\
\hline $\begin{array}{l}\text { bad interpretation of procedures } \\
\text { and regulations }\end{array}$ & 0 & 0.00 & 7 & 6.42 & 13 & 11.93 & 71 & 65.14 & 18 & 16.51 & 3.9 & 0.7 & 0.593 \\
\hline internal control deficiencies & 0 & 0.00 & 7 & 6.42 & 16 & 14.68 & 68 & 62.39 & 18 & 16.51 & 3.9 & 0.7 & 0.470 \\
\hline $\begin{array}{l}\text { too many administrative } \\
\text { workers }\end{array}$ & 9 & 8.26 & 48 & 44.04 & 19 & 17.43 & 25 & 22.94 & 8 & 7.34 & 2.8 & 1.1 & $<0.001$ \\
\hline lack of knowledge sharing & 10 & 9.17 & 40 & 36.70 & 18 & 16.51 & 30 & 27.52 & 11 & 10.09 & 2.9 & 1.2 & 0.002 \\
\hline employee laziness & 2 & 1.83 & 14 & 12.84 & 14 & 12.84 & 52 & 47.71 & 27 & 24.77 & 3.8 & 1.0 & 0.679 \\
\hline
\end{tabular}


Table 7. Types of medical improvements according to hospital directors

\begin{tabular}{|c|c|c|c|c|c|c|c|c|c|c|c|c|}
\hline \multirow[t]{2}{*}{ Specification } & \multicolumn{2}{|c|}{$\begin{array}{c}\text { strongly } \\
\text { disagree (1) }\end{array}$} & \multicolumn{2}{|c|}{$\begin{array}{c}\text { disagree } \\
\text { (2) }\end{array}$} & \multicolumn{2}{|c|}{$\begin{array}{l}\text { undecided } \\
\text { (3) }\end{array}$} & \multicolumn{2}{|c|}{ agree (4) } & \multicolumn{2}{|c|}{$\begin{array}{l}\text { strongly } \\
\text { agree (5) }\end{array}$} & \multicolumn{2}{|c|}{ total } \\
\hline & $\mathrm{n}$ & $\%$ & $\mathrm{n}$ & $\%$ & $\mathrm{n}$ & $\%$ & $\mathrm{n}$ & $\%$ & $\mathrm{n}$ & $\%$ & $\mathrm{M}$ & SD \\
\hline $\begin{array}{l}\text { frequent analyses of the scope of } \\
\text { employee's job description }\end{array}$ & 0 & 0.00 & 2 & 9.52 & 9 & 42.86 & 10 & 47.62 & 0 & 0.00 & 3.4 & 0.7 \\
\hline defining a new job description & 0 & 0.00 & 3 & 14.29 & 10 & 47.62 & 8 & 38.10 & 0 & 0.00 & 3.2 & 0.7 \\
\hline $\begin{array}{l}\text { introducing increased supervision over } \\
\text { following procedures }\end{array}$ & 0 & 0.00 & 0 & 0.00 & 1 & 4.76 & 16 & 76.19 & 4 & 19.05 & 4.1 & 0.5 \\
\hline $\begin{array}{l}\text { more frequent organisation of training } \\
\text { courses }\end{array}$ & 0 & 0.00 & 1 & 4.76 & 3 & 14.29 & 17 & 80.95 & 0 & 0.00 & 3.8 & 0.5 \\
\hline $\begin{array}{l}\text { strengthening communication between } \\
\text { health professionals }\end{array}$ & 0 & 0.00 & 1 & 4.76 & 1 & 4.76 & 12 & 57.14 & 7 & 33.33 & 4.2 & 0.7 \\
\hline
\end{tabular}

$\mathrm{n}$ - number of respondents, \% - share of respondents $(\mathrm{N}=21) . \mathrm{M}$ - mean, SD - standard deviation

Source: Author.

Table 8. Types of medical improvements according to the nursing staff

\begin{tabular}{|c|c|c|c|c|c|c|c|c|c|c|c|c|c|}
\hline \multirow[t]{2}{*}{ Specification } & \multicolumn{2}{|c|}{$\begin{array}{l}\text { strongly } \\
\text { disagree } \\
\text { (1) }\end{array}$} & \multicolumn{2}{|c|}{$\begin{array}{l}\text { disagree } \\
\text { (2) }\end{array}$} & \multicolumn{2}{|c|}{$\begin{array}{l}\text { undecided } \\
\text { (3) }\end{array}$} & \multicolumn{2}{|c|}{ agree (4) } & \multicolumn{2}{|c|}{$\begin{array}{l}\text { strongly } \\
\text { agree }(5)\end{array}$} & \multicolumn{2}{|c|}{ total } & \multirow[t]{2}{*}{$\mathrm{p}$} \\
\hline & $\mathrm{n}$ & $\%$ & $\mathrm{n}$ & $\%$ & $\mathrm{n}$ & $\%$ & $\mathrm{n}$ & $\%$ & $\mathrm{n}$ & $\%$ & $\mathrm{M}$ & SD & \\
\hline $\begin{array}{l}\text { frequent analyses of the scope of } \\
\text { employee's job description }\end{array}$ & 3 & 2.75 & 24 & 22.02 & 25 & 22.94 & 43 & 39.45 & 14 & 12.84 & 3.4 & 1.1 & 0.876 \\
\hline defining a new job description & 2 & 1.83 & 38 & 34.86 & 21 & 19.27 & 34 & 31.19 & 14 & 12.84 & 3.2 & 1.1 & 0.757 \\
\hline $\begin{array}{l}\text { introducing increased supervision } \\
\text { over following procedures }\end{array}$ & 8 & 7.34 & 43 & 39.45 & 13 & 11.93 & 35 & 32.11 & 10 & 9.17 & 3.0 & 1.2 & $<0.001$ \\
\hline $\begin{array}{l}\text { more frequent organisation of } \\
\text { training courses }\end{array}$ & 4 & 3.67 & 37 & 33.94 & 16 & 14.68 & 41 & 37.61 & 11 & 10.09 & 3.2 & 1.1 & 0.021 \\
\hline $\begin{array}{l}\text { strengthening communication } \\
\text { between health professionals }\end{array}$ & 5 & 4.59 & 55 & 50.46 & 15 & 13.76 & 22 & 20.18 & 12 & 11.01 & 2.8 & 1.1 & $<0.001$ \\
\hline
\end{tabular}

